$\operatorname{cocos},(1984), 18-28$

Printed in Sri l.anku

\title{
Importance of energy management in desiccated coconut industry
}

\author{
W.J.N. FERNANDO., and T. THANGAVEL. \\ Department of Chemical Engineering, University of Peradeniya, Sri Lanka.
}

\begin{abstract}
A B S T R A C T
Energy flow rates across commony used desiccators and associated heat transfer equipment are quantified. It is seen that approximately 726 percent excess heat energy over the actual requirement is presently used for drying in desiccators. Approximately 49 percent of heat energy is exhausted to the atmosphere through the chimney and approximately 23 percent along with the deaiccator exhaust gases. Approximately $\mathbf{4 0}$ percent of energy could be saved by introducing recirculation techniques of heat recovery. This saving represents about 83.2 million kwh of energy for 1981 alone, which is an equivalent of 4.5 percent of the total electrical energy generated in Sri Lanka in 1981.
\end{abstract}

\section{INTRODUCTION}

The commonly used process of manufacture of desiccated coconut is a batchwise process. Two types of drying equipment presently in operation in Sri Lanka, namely, desiccators which are loaded and unloaded manually and dryers with a semi automatic arrangement for loading and unloading. These are designed for indirect heating from flue gases obtained by either combustion of firewood or oil firing. The ambient air at approximately $30^{\circ} \mathrm{C}$ is sent through a heat exchanger. Combustion gases leaving the furnace enters the heat exchanger as the heating medium. Indirect heat transfer from combustion gases to the desiccator air increases the temperature of the desiccator air. Used combustion gases leave the heat exchanger via a chimney as a flue gas. The average drying temperature inside the desiccator is around $88^{\circ} \mathrm{C}$ $\left(190^{\circ} \mathrm{F}\right)$. Under these conditions the drying process takes approximately 45 minutes. The normal inlet temperature of air is approximately $130^{\circ} \mathrm{C}\left(266^{\circ} \mathrm{F}\right)$ and the outlet temperature approximately $88^{\circ} \mathrm{C}\left(190^{\circ} \mathrm{F}\right)$.

In 1982 seventy five factories were engaged in the manufacture of desiccated coconut in Sri Lanka. The overall production capacity of these factories in 1982 was around 60,000 metric tonnes of desiccated coconut estimated on the basis of an 8-hours working day and 200 working days per year (Ministry of Coconut Industries, 1982). 


\section{Energy management in the desiccated coconut industry}

The average consumption of firewood per ronne of desieciated coconul is approximatly 1.05 tomnes 13.5 yards) (Nattandiya Coconut Producers Co-op Socicty LTd.. 1983) representing in overall requirement of about 63.000 tonnes of firewood per year.

The following section presents an energy analysis of the production process.

\section{ENERG Y A NALYSIS}

\section{Excess Energy}

The average moisture content of shredded kernel priur 10 desiccation is $\mathbf{4 3}$ perceit on wel basis. The average moisture content to which the shredded kernel is dried within the desiccator is 3 percent on a wet basis. The average temperature within the desiccator is $88^{\circ} \mathrm{C}$. The theoretical heat requirement for heating shredded kernel from an ambient temperature of $30^{\circ} \mathrm{C}$ to $88^{\circ} \mathrm{C}$ and for the removal of moisture from 43 percent to 3 percent is $2.227 \times 10^{6}$ kJ Ionne of desiccated coconut. (See Appendix 1).

The process of drying of desiccated coconut usually required approximately 1.05 tonnes of firewood per tonne of desiccated coconut. The average moisture content of firewood in the western coastel belt of Sri Lanka between Chilaw and Colombo where the desiccated coconut mills are usually situated was found to be 13.77 percent on dry basis. The variation of calorific value of firewood with the moisture content is shown in Fig. I. The nett calorific value of firewood at 13.77 percent moisture content is $17.235 \mathrm{~kJ} / \mathrm{kg}(7420 \mathrm{Btu} / \mathrm{lb})$. The actual heat generated in the process of drying one tonne of desiccated coconut is therefore $18.405 \times 10^{6} \mathrm{~kJ}$.

The energy generated in excess of the requirement for drying one tonne of desiccated coconut is therefore $16.178 \times 10^{6} \mathrm{~kJ}$. This represents an energy generation of 726.45 percent in excess of the theorctical requirement. (See Appendix 2)

\section{A P PR OPRIATION ENERGIES}

\section{Energy Balance Across Desiccalor}

The average drying temperature within a desiceator is $88^{\circ} \mathrm{C}$. If complete mixing is assumed within a desiccator, the exit air stream from the desiccator may be assumed io leave at a temperature of $88^{\circ} \mathrm{C}$. The average flow rate of air through adesiccatoris estimated to be $\mathbf{7 4 0 0}$ $\mathrm{kg}$ air per hour (See Appendix 3). The rate of muisture removal by this stream is $77.23 \mathrm{~kg} / \mathrm{hr}$. Estimated temperature of air inlet to the desiceator is $130.0^{\circ} \mathrm{C}$ (See Appendix 3). Taking the datum as the ambient conditions for energy measurements, the energy flow rates per tonne of desiccated coconut at the inlet and exit of the desiccator are $67.67 \times 10^{5} \mathrm{~kJ}$ respectively. 


\section{W.J.N. PBRNANDO and T. THANGAVBC}

The accounted energy loss from the desiccator is $2.28 \times 10^{5} \mathrm{~kJ}$ per tonne of desiccated coconut.

Energy Balanct Across the Furnaec

Ambient air of zero energy flow rate (datum at ambient conditions) enters the combustion chamber in which $184.05 \times 10^{5} \mathrm{~kJ}$ of heatper tonne of desiccated coconut is generated by combustion of firewood (Appendix 2). If 10 percent of this is assumed to be lost to the atmosphere due to radiation and other effects, this amounts to $18.405 \times 10^{5} \mathrm{~kJ}$ per tonne of desiccated coconut. Heat balance across the furnace gives a flow rate of $165.645 \times 10^{5} \mathrm{~kJ}$ of energy per tonne of desiccated coconut being carried away by combustion gases from the furnace to the heat exchanger.

The energy balance across the furnace is shown in Fig. 2.

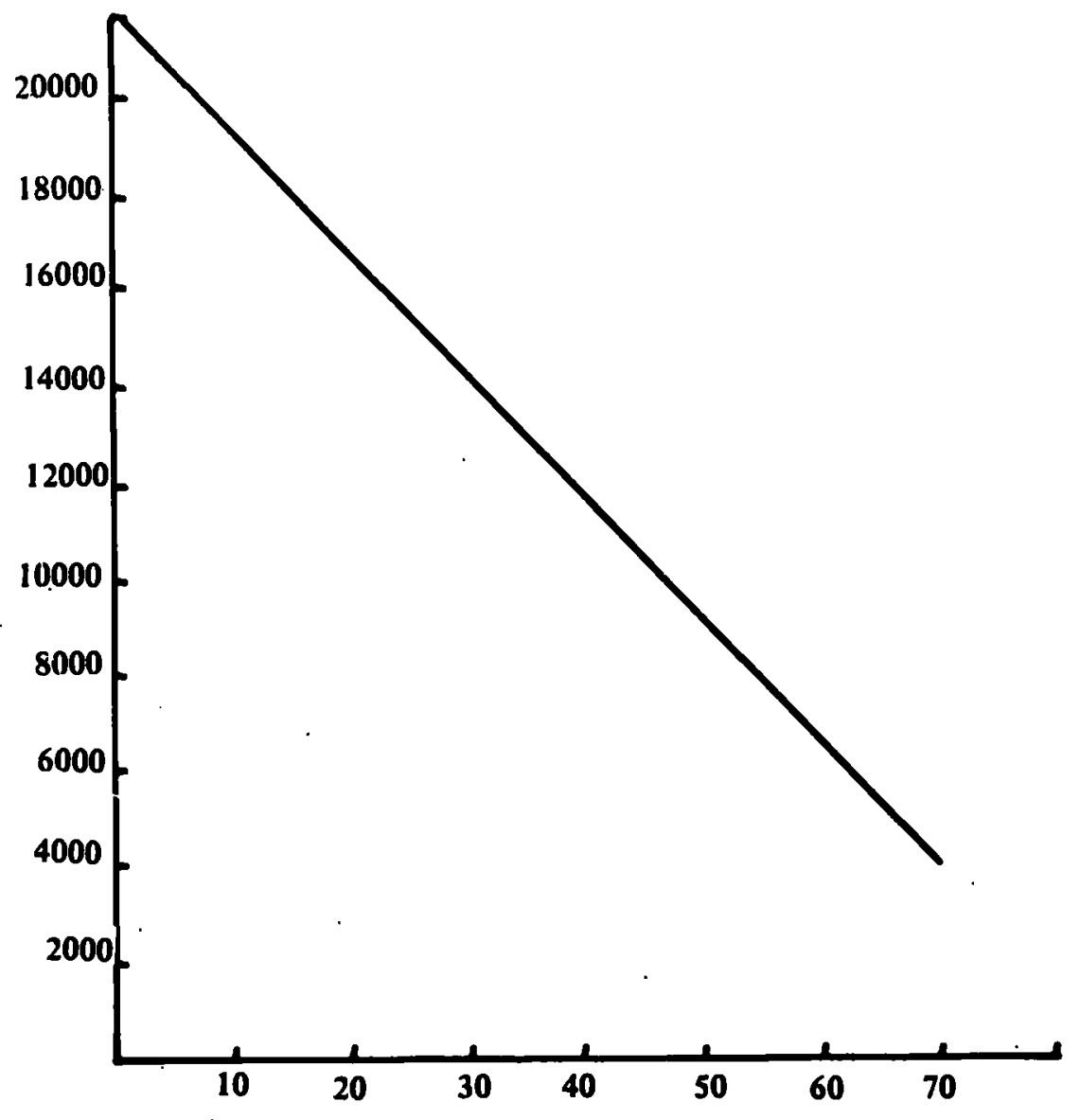

Fig 1. Net calorific value of wood as a function of moisture content (dry basis) 
Encrgy management in desiccated coconutIndustry

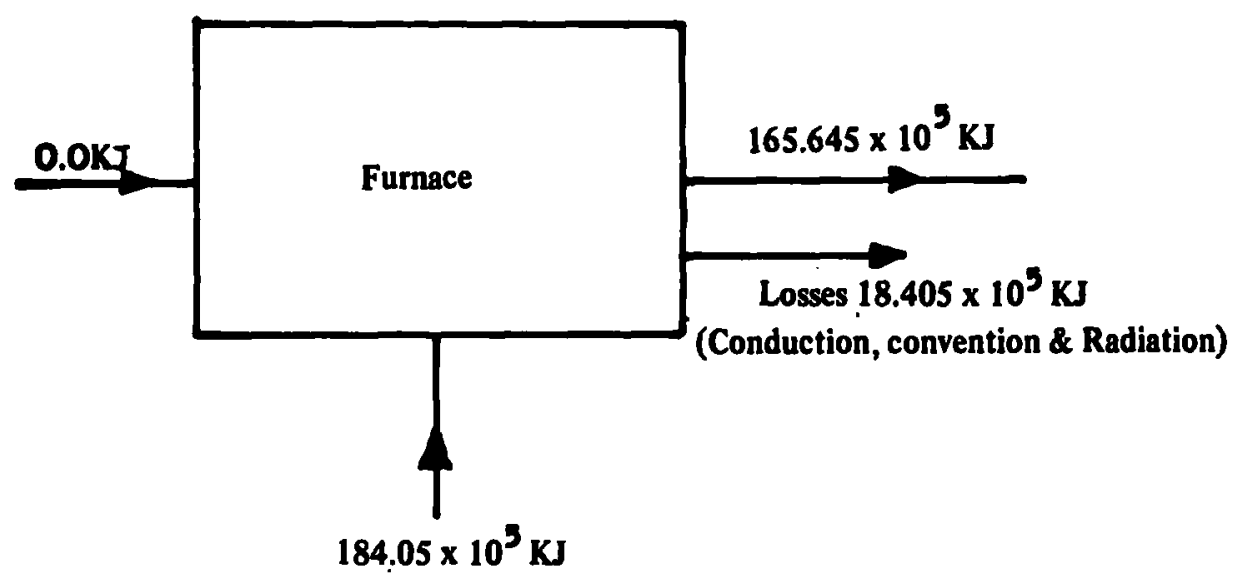

Fig 2. Energy balaince acruss furnace (basis : 1 tonne desiccated coconut \&. $30^{\circ} \mathrm{C}$ as datum,

\section{Enurgy BalanceAcross the Heat Exchanger}

The air flow into the desiccator enters the heat exchanger at embient conditions, representing a zero energy flow rate. The air stream is heated to a temperature of $130.0^{\circ} \mathrm{C}$ of energy flow rate $67.67 \times 10^{5} \mathrm{~kJ}$ per tonne of desiccated coconut.

If 10 percent of energy is assumed to be lost to the atmosphere, this represents 6.767 $\times 10^{5} \mathrm{~kJ}$ per tonne of desiccated coconut. The combustion gases entering the heat exchanger is of an energy content $165.645 \times 10^{5} \mathrm{~kJ}$ per tonne of desiccated coconut. A heat balance across the heat exchanger reveals that $91.208 \times 10^{5} \mathrm{~kJ}$ per tonne of desiccated coconut is lost to the atmosphere through the chimney.

\section{Discussion}

Fig 3 is a heat balance chart for the process of desiccated coconut manufacture showing the energy flow rates entering and leaving the furnace, heat exchanger and the desiccator. It can be seen that 49 percent of energy generated by firewood combustion escape through the chimney to the atmosphere. 23.42 percent of energy generated by combustion is seen to escape through the exhaust from the desiccator. This indicates 63.72 percent of the useful energy in the form of hot air entering the desiccator is lost via exhaust from the desiccator. It has been shown (Fernando, W.J.N. and Thangavel T., 1983) that about 40 percent of the energy lost could be saved by introducing recirculation techniques to the manufacturing process of desiccated coconut. This represents saving of 83.2 million $\mathrm{kwh}$ of energy for a production of 40,685 tonnes of desiccated coconut which was the output in 1981 . This also represents an energy equivalent of approximately 4.5 percent of power generated by the Ceylon Electricity Board in that year. In terms of firewood the saving represents approximately 17,087 tonnes of firewood. 


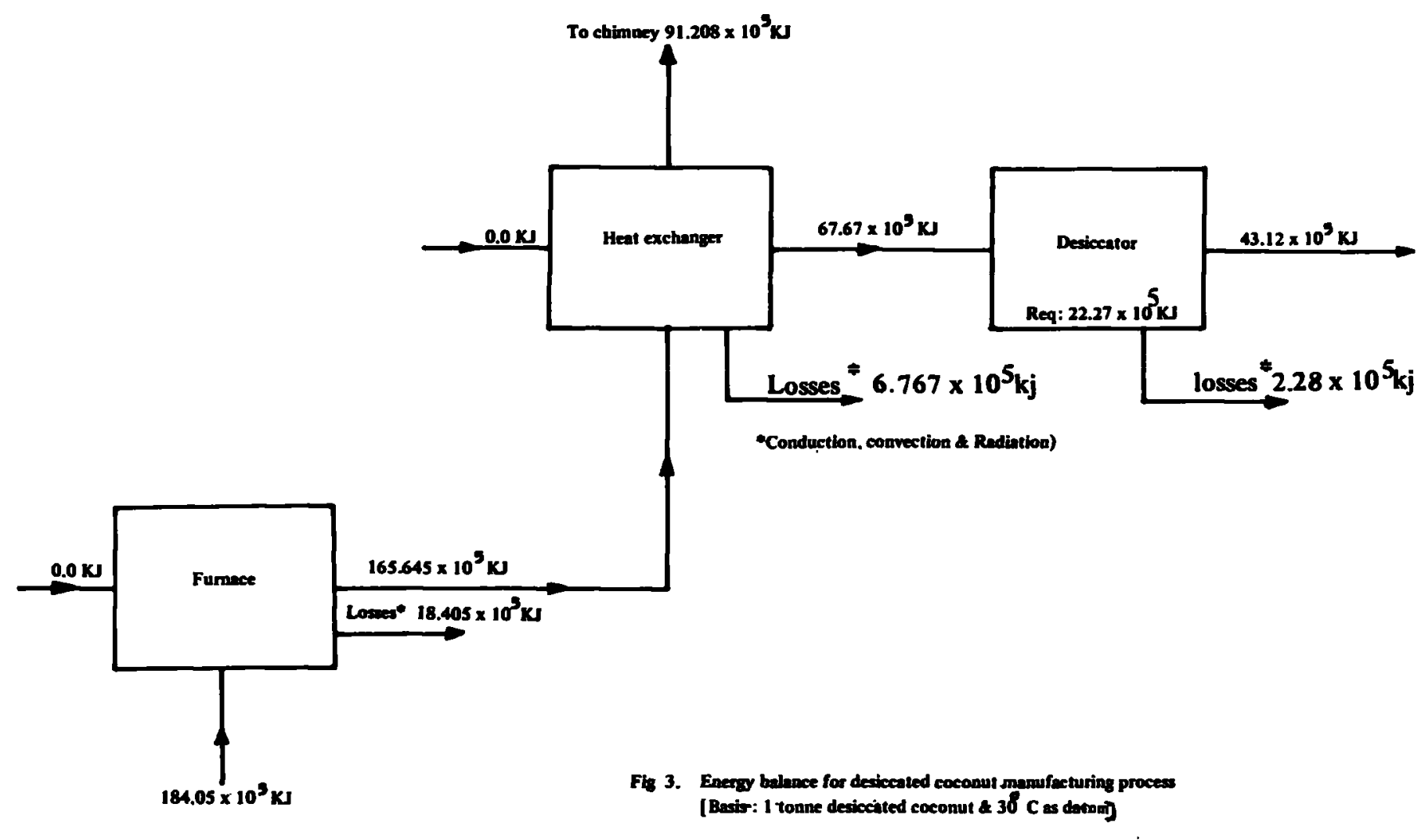


Energy management in the desiccated coconut Industry

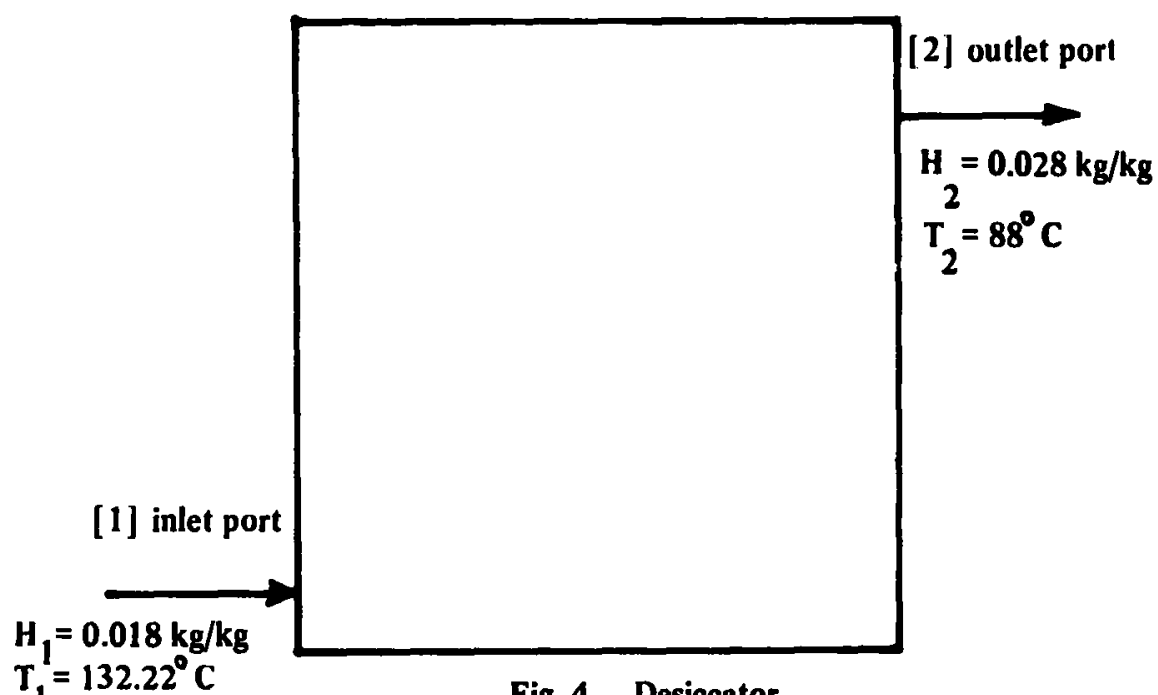

Fig 4. Desiccator

The whole desiccator process generates approximately 726 percent of energy in excess of the actual requirement for drying. Annually this amounts to a wastage of 269.63 million kwh of energy for a production rate of 60,000 tonnes of desiccated coconut which is the full capacity of the industry. This amounts to an equivalent of 14.40 percent of power generated by the Ceylon Electricity Board in 1981. It is evident, from this anslysis, that the management of energy in the desiccated coconut industry of Sri Lanka is not satisfactory. If the large amount of heat which is now, is properly utilized the profits from this industry would rbe appreciably and the contriburion to the national energy saving efforts would be aubatantial.

\section{R E F E R E N C ES}

Central Bank of Ceylon. (1982) Annual Report.

Femando, W.J.N. and Thangavel, T. (1983) Energy.

Conservation in Desiccated Coconut Drying, Trans. Inst. Engineers, Srl Lanka, $49-61$

Ministry of Coconut Industries (1982). Sri Lanka Coconut Statistics 1982

Nettanaiya Coconut Producers Ca-op Society Ltd., (15.08.1983) Private Communication.

Perry, John H. (1983) Chemical Engineers' Hand Book, 26/25P 4th ed, McGraw - Hill Book Ca.. Tokyo. 


\section{W.J.A. FERMANDO and T. THMTCAVET}

Appendix 1

Energy Requirement : (Basis 1 tonne of desiccated coconut)

Moisture content of shredded coconut before

$\begin{array}{llr}\begin{array}{c}\text { drying } \\ \text { Moisture content of desiccated coconut }\end{array} & =43 \% \text { wet basis } \\ \text { The amount of moisture removed per tonne of } & \\ \text { desiccated coconut } & =701.8 \mathrm{~kg}\end{array}$

The shredded coconut is to be heated from an ambient temperature of $30^{\circ} \mathrm{C}$ to $88^{\circ} \mathrm{C}$ prior to drying Energy required for heating shredded coconut from $30^{\circ} \mathrm{C}$ to $88^{\circ} \mathrm{C}=$ Energy required for heating desiccated coconut from $30^{\circ} \mathrm{C}$ to $88^{\circ} \mathrm{C}$ + Energy required for heating balance moisture from $30^{\circ} \mathrm{C}$ to $88^{\circ} \mathrm{C}$

Specific heat of desiccated coconut

Heat required for hesting of desiccated coconut from $30^{\circ} \mathrm{C}$ to $88^{\circ} \mathrm{C}$

Heat required for heating $701.8 \mathrm{~kg}$ of moisture

Heat required to eveporate moisture at $88^{\circ} \mathrm{C}$

Total Heat requirement
$=1.87 \mathrm{KCal} / \mathrm{kg}^{\circ} \mathrm{C}$ (by experiment)

$$
\begin{aligned}
& =1000 \times 1.87 \times 58 \\
& =108,460 \mathrm{kCal}
\end{aligned}
$$

$=\quad 701.8 \times 1.0 \times 58$

$=40,704.4 \mathrm{kCal}$

$=701.8 \times 545.96$

$=\quad 383154.7 \mathrm{kCal}$

$=(383154.7+40704.4$ $+108460) \times 4.185$

$=2.227 \times 10^{6} \mathrm{~kJ}$ 
. Energy management in the desiccated coconut Industry

Appendix 2

\section{Excess Energy}

The average moisture content of firewood on the western coast of Sri Lanka where the desiccated coconut mills are usually situated

$=13.77 \%$ dry basis.

The variation of calorific value of firewood vs moisture content obtained experimentally is shown in Fig. 1 .

The nett calorific value of firewood at $13.77 \%$ moisture content

$=17,235 \mathrm{~kJ} / \mathrm{kg}$ (7420 Btu/lb)

Firewood requirement per tonne of desiccated coconut

$=21 \mathrm{cwt}$ Approximately 1.05 tonnes

The heat generated to dry one tonne of

$$
\begin{aligned}
\text { desiccated coconut } \quad & 7420 \times 21 \times 112 \\
\times \quad & =18.405 \times 10^{6} \cdot \mathrm{kJ}
\end{aligned}
$$

The excess energy generated to dry one tonne

$$
\begin{aligned}
& \text { of desiccated coconut }=(18.405-2.227) \\
& \times 10^{6} \mathrm{~kJ} \\
&= 16.178 \times 10^{6} \mathrm{~kJ}
\end{aligned}
$$

. The excess energy generated as percentage of

$$
\text { requirement. }
$$

$=16.178 \times 100 \%$

$=726.45 \%$ 


\section{W.J.N. PBRNANDO and T. THAMTGAVEU}

Appendix 3

Heat Analysis across Desiccator

The quantity of wet shredded coconut which could be spread on one tray

$=50 \mathrm{lbs}$

The quantity of desiccated coconut produced per

$=50 \times \frac{57}{100} \times \frac{100}{97}$

$=29.38 \mathrm{lbs}$

A double desiccator contains six trays

Total desiccated coconut per batch

$=29.38 \times 6 \times 0.454$

$=80.03 \mathrm{~kg}$.

To manufacture one tonne of desiccated coconut

$$
\begin{aligned}
\text { the number of batches required } & =\frac{1000}{80.03} \\
& =12.45 \text { Batches }
\end{aligned}
$$

The operating time of desiccator for the production one tonne of desiccated coconut

$=12.45 \times 45$

$=562.5 \mathrm{mts}$

$=9.375 \mathrm{hr}$

The head developed by the fan

$$
\begin{aligned}
& \text { Motor Horsepower } \\
& \text { Fan efficiency }
\end{aligned}
$$

$=7.5$

$=0.55$

Air flow rate through the desiccator

(Perry, 1963) $=\frac{(7.5 \times 0.55 \times 550 \times 3600 \times 0.453)}{500}$ 


\section{Energy management in the desiccated coconut Indusin.}

Measurements taken at the factury confirms the above value of air flow rate

Moisture removal per hour

$$
\begin{aligned}
& =\begin{array}{l}
724 \mathrm{~kg} / \text { tonne of } \\
\text { desiccated coconut }
\end{array} \\
& =\frac{724}{9.375} \\
& =77.23 \mathrm{~kg} / \mathrm{hr}
\end{aligned}
$$

The average conditions of almosphere

represents an air humidity of $0.18 \mathrm{~kg} / \mathrm{kg}$ dry air Fig. 4 represents the inlet and outlet ports of air 10 and from a desiccotor respectively.

Let $\mathrm{H}_{2}$ and $\mathrm{H}_{2}$ be the humidities of air at entry and exit to desiccator, respectively. $\mathbf{H}_{\mathbf{1}}$

$=0.018 \mathrm{~kg} / \mathrm{kg}$

Evaporation rate in the desiccator

$=\quad 77.23 \mathrm{~kg} / \mathrm{hr}$

Air flow rate through the desiccator

$=7400 \mathrm{~kg} / \mathrm{hr}$

$$
\therefore \mathrm{H}_{2}
$$

$=0.018+\frac{77.23}{7400}$

The specific enthalpy of air at port (2)

$=0.028 \mathrm{~kg} / \mathrm{kg}$ dry air

$=\quad 77.7$ Btu/lb dry air

Assuming $10 \%$ of the heat is lost to the atmosphere

Air heat supply to the desiccator

$=2,227 \times 10^{6} \times 1.1 \mathrm{~kJ} /$ tonne

$=\frac{1.1 \times 2.227 \times 10^{6}}{7400 \times 9.375}$

$=\quad 35.31 \mathrm{~kJ} / \mathrm{kg}$

$=\quad 15.20 \mathrm{Btu} / \mathrm{lb}$ dry air

Enthalpy at port (1)

$=77.7+15.20$

$=92.9 \mathrm{Btu} / \mathrm{lb}$ 


\section{W.J.R. PRRNANDO and T. THaMGaVRI \\ Humidity at port (1) $\quad=0.018 \mathrm{~kg} / \mathrm{kg}$}

By reference to standard psychrometric charts inlet temperature

$=130^{\circ} \mathrm{C}(266 \mathrm{~F})$

Assuming ambient conditions at $30^{\circ} \mathrm{C}$

represent the datum for energy, Energy flow rate at port (2) per tonne of desiccated coconut

$=$ Flow rate of air $\mathrm{xh}_{\mathbf{2}}$

-Flow rate of air $x h_{x}$

$=7400 \times(77.7-51.0) \times 9.375$

Btu/Tonne

$=43.12 \times 10^{5} . \mathrm{kJ} /$ tonne

(where $h_{x}$ is the enthalpy of air and associated water vapour at $30^{\circ}$ )

Energy flow rate at port (1) per tonne of desiccated coconut

$$
\begin{aligned}
& =\frac{7400}{0.453} \times(92.9-51.0) \times 9.375 \\
& \text { Btu/tonne } \\
& =67.67 \mathrm{~kJ} / \text { tonne }
\end{aligned}
$$

Theoretical heat loss from the desiccator per tonne of desiccated coconut $=$ Enthalpy of entering stream . Enthalpy of gas stream leaving - (Heat required for initial heating up of 1 tonne desiccated coconut and associated moisture + latent heat of evaporation of moisture associated with 1 tonne of desiccated coconut)

$$
\begin{aligned}
& =\underset{\mathrm{kJ} / \text { tonne }}{(67.67-43.12-22.27) \times 10^{5}} \\
& =2.28 \times 10^{5} \mathrm{~kJ} / \text { tonne }
\end{aligned}
$$

Energy loss to the atmosphere via exhaust air of desiccator as a \% of requirement

$$
\begin{aligned}
& =\frac{43.12}{22.27} \times 100 \% \\
& =193.62 \%
\end{aligned}
$$

